(8)

special articles research strategy. An early example might be the incorporation of results from the cross-institutional study (described above) into the standards: robust results about what matters in therapeutic communities will be discussed at a stakeholder conference and incorporated by the democratic process.

This is more than an audit cycle because it will be producing new knowledge (about what defines a therapeutic community, and what is good practice within one) and bringing about structural change in systems (new ways of doing things). It is an action research project because it will gain its legitimacy through a consensual process involving all involved parties: all the stakeholders 'own' the emerging results. It is a coherent way of ensuring and improving quality while bringing about coordinated and research-based change. Furthermore, it institutionalises the process of change, so therapeutic communities become responsive to the superordinate systems upon which they rely for survival. They will need to continually negotiate their place among other communities and other treatment modalities by maintaining a culture of enquiry (Main, 1967; Norton, 1992) about their own practice.

\section{References}

AMERICAN PSYCHIATRIC ASSOCIATION (1987) Diagnostic and Statistical Manual of Mental Disorders (3rd edn revised) (DSM-111-R). Washington DC: APA.

ASSOCIATION OF THERAPEUTIC COMMUNITIES (1999) A Comparative Evaluation of Therapeutic Community Effectiveness for People with Personality Disorders. At: http:// www.therapeuticcommunities.org/ lottery-protocol.htm. methodology and treatment effects. British Journal of Psychiatry, 176 485-491.

-, ICCOPONI, E. \& MORRIS, M. (1996) Changes in healthy service utilization by patients with severe borderline personality disorder before and after inpatient psychosocial treatment. British Journal of Psychotherapy, 124 501-512.

DAVIS, S. (1999) Survival and growth in the market place: does every district need aTC? InTherapeutic Communities Past, Present and Future (eds $P$. Campling \& R. Haigh), pp. 223-234. London: Jessica Kingsley Publishers.

- CAMPLING, P. \& RYAN, K. (1999) Therapeutic community provision at regional and district levels. Psychiatric Bulletin, 23, 79-83.

DEPARTMENT OF HEALTH (1999) A

National Service Framework for Mental Health: Modern Standards and Service Models. London: Stationery Office.

DOLAN, B. M., WARREN, F. M., MENZIES, D., et al (1996) Cost offset following specialist treatment of severe personality disorders. Psychiatric Bulletin, 20, 413-417.

HAIGH, R. (2000) Psychosocial treatment programmes for personality disorder: service developments and research (letter). British Journal of Psychiatry, 177, 281

— \& STEGAN, G. (1996) Inpatient psychotherapy (letter). British Journal of Psychiatry, 168, 524

KENNARD, D. (1999) Introduction to Therapeutic Communities. London: Jessica Kingsley Publishers.

LEES, J. (1999) Research: the importance of asking questions. In: Therapeutic Communities Past, Present and Future (eds P. Campling \& R. Haigh) London: Jessica Kingsley Publishers.

-, MANNING, N. \& RAWLINGS, B. 1999) Therapeutic Community Effectiveness. A Systematic International Review of Therapeutic CommunityTreatment for People with Personality Disorders and Mentally Disordered Offenders, (CRD Report 17). York: NHS Centre for Reviews and Dissemination, University of York.

LEWIS, S. (1993) Dartmouth House Centre. Therapeutic Communities, 14 127-133.

MAIN, T. F. (1946) The hospital as a therapeutic institution. Bulletin of the Menninger Clinic, 10, 66-70. Reprinted inTherapeutic Communities (1996) 17, 77-80.

— (1967) Knowledge, learning and freedom from thought. Australia and New Zealand Journal of Psychiatry, 1 , 64-71. Reprinted in Psychoanalytic Psychotherapy 5, 49-78.

MARSHALL, P. (1997) A Reconviction Study of HMP GrendonTherapeutic Community. Home Office Research and Statistics: Research Findings Number 53.

NORTON, K. (1992) A culture of enquiry - its preservation or loss. Therapeutic Communities, 13, 3-25.

RAPOPORT, R. N. (1960) Community as Doctor New Perspectives on Therapeutic Community. London: Tavistock Publications.

RAWLINGS, B. (1998) The therapeutic community in the prison: problems in maintaining therapeutic integrity.

Therapeutic Communities, 19
Rex Haigh Consultant Psychotherapist, Winterbourne House, 53-55 Argyle Road, Reading RG1 7YL; e-mail: rex.haigh@virgin.net

Psychiatric Bulletin (2002), 26, 68-70

S. J. CAREY, D. J. HALL AND G. A. JONES

\title{
Grand rounds: catatonia
}

Classical cases of catatonia in schizophrenia have become much less frequent with the introduction of neuroleptic drugs (Blumer, 1997), and psychiatrists practising in Western countries may well have seen few cases. Neuroleptic malignant syndrome (NMS), however, continues to occur in between $0.02 \%$ and $0.4 \%$ of patients and may occasionally prove fatal (Addonizio et al, 1986). We report a case with features of both these conditions.

\section{Case history}

The patient, 51 years old, was first admitted to hospital in 1966 at age 19. He was noted to have a "fear of death" and "increased sexual desire", and a "very abnormal electroencephalogram" and an encephalopathy resembling leucoencephalitis was suggested. Since childhood the patient was said to have had "tics and mannerisms".

A diagnosis of schizophrenia was made in 1967, when he was 20 years of age, and he has needed over 14 further admissions presenting with a number of delusions. He has been an in-patient continuously since 1986, when he was aged 39. Over the years a wide range of antipsychotic medication (including chlorpromazine, thioridazine, trifluoperazine, perphenazine, haloperidol, fluphenazine and benperidol) has been required, often in substantial doses.

In recent times he has suffered persistent, though variable, symptoms of psychosis, stereotypies, mannerisms, 
evidence of tardive dyskinesia and possible torsion dystonia. His drug treatment prior to this exacerbation consisted of fluphenazine decanoate depot, oral benperidol and diazepam.

A dramatic change in his condition occurred in October 1998. He became restless and self-care worsened. He heard voices from God about damnation, and felt guilty and worthless. He felt he might soon die. He felt thoughts inserted into his mind, and experienced the feeling of being pushed against the walls. Over 10 days he needed a total dose of $650 \mathrm{mg}$ of zuclopenthixol acetate intramuscular, with additional droperidol and diazepam as required. He had a number of bruises from falling and the need for restraint. His creatinine kinase level was raised at $4960 \mathrm{iu} / \mathrm{l}$, as was the neutrophil count; heart rate was 116 per minute. He suffered periods of screaming and apparent rigidity.

Transfer to the adjacent general medical unit was undertaken. He remained ill, and very distressed. He was sweating markedly and blood pressure was labile. His limbs became increasingly rigid, and attempted movement was very painful. For a time he was unresponsive, moving only his eyes. Temperatures spiked, up to $38.9^{\circ} \mathrm{C}$, and respiration was impaired. Cortisol levels were raised. Analysis of the raised creatinine kinase level showed it to be of muscle rather than cardiac origin. An Escherichia coli urinary infection was identified and treated. A lumbar puncture was undertaken, but the cerebrospinal fluid was normal. Computerised tomograms of the head were also normal. Benzodiazepines and anticholinergic medication were required on a number of occasions.

The patient, however, remained significantly distressed and delusional and required electroconvulsive therapy (ECT). He improved swiftly and substantially, returning to his state of health prior to this exacerbation. He was prescribed risperidone, and for the emergence of affective features, lithium was added. Following a relapse requiring further ECT, clozapine was started - and valproate later added following an epileptic fit. He has also required low dose thioridazine and diazepam. However, he is currently fairly well, with no active psychoses or affective symptoms.

\section{Discussion}

Catatonia was first described by Kahlbaum in 1874 (Kahlbaum, 1973). It is seen in affective and schizophrenia disorders, and is characterised by abnormalities of movement including posturing, stereotypies and waxy flexibility. Language abnormalities may also be present and include echolalia and verbigeration (Murray et al, 1997). In the past chronic catatonia states were common sequelae of encephalitis lethargica; now that this is no longer epidemic, catatonia has lessened in frequency in psychiatric hospitals (Johnson, 1993), but is still reported to occur with regularity in district hospital units. Treatment is to avoid neuroleptics, possibly prescribe benzodiazepines and ECT is of value.

The NMS was first described in the English language literature by Delay and Deniker in 1968. The onset is some
2-28 days after receiving neuroleptics. Muscular rigidity, akinesia, pyrexia, clouding of consciousness and autonomic changes may be present - the latter including hypertension, sweating, pallor and urinary incontinence; there may be a neutrophilia, raised creatinine phosphokinase (CPK; an enzyme released in muscle damage) and raised potassium levels (Murray et al, 1997).

It may last 5-10 days after drug discontinuation, but longer with depot preparations. There is no treatment proven to be effective, but bromocriptine and dantrolene have been used. It has been more recently suggested that CPK levels are raised in catatonic patients, and this is related to dyskinetic movements (Northoff et al, 1996). The coexisting E. coli urinary tract infection from which this patient suffered did complicate the clinical picture, and may have contributed to the pyrexia and neutrophilia.

Forty years ago, here in Dumfries, Mayer-Gross, in a text influential in its time, drew attention to coexisting physical illnesses: he felt that they were the immediate cause of death in such cases, and the patients' abnormal behaviour impeded their diagnosis (Mayer-Gross et al, 1960; Kellam, 1987). Again, more recently, it has been suggested that NMS is not an unitary syndrome, but could represent extrapyramidal side-effects (EPS) complicated by medical disorders - with dehydration, infection, pulmonary embolism and rhabdomyolysis being common complications of untreated EPS (Levinson \& Simpson, 1986). Features common to both catatonia and NMS are increasingly recognised, with the NMS felt to closely represent advanced catatonia; similar syndromes with unexplained fulminating hyperpyrexia, usually in the setting of catatonia, have been noted since the beginning of the 19th century, well before the development of neuroleptics (Kellam, 1987). A common neurochemical basis has been postulated for catatonia and NMS: a massive blockade of dopamine receptors, previously hyper-stimulated by psychoses or by dopamine blocking drugs (Osman \& Khurasani, 1994), and both share a common beneficial response to ECT. Patients with past or present catatonic symptoms are particularly vulnerable to NMS (Blumer, 1997).

This is a complex and partially understood area, but one that deserves a high level of awareness both owing to the morbidity and mortality that may occur, and to the fact that treatment may be effective. While some literature suggests that lethal catatonia often requires neuroleptic treatment (Castillo et al, 1989), it is more widely held that, as mentioned in a review article: "Although the mental blockade effected by routine early prescription of neuroleptics appears to prevent emergence of the previously plentiful catatonic symptoms in schizophrenia, once catatonic signs are already present the neuroleptics must be avoided because of the risk of severe catatonia with NMS. For the same reason, neuroleptics should be prescribed with caution for patients with a history of catatonia." (Blumer, 1997)

This patient had no history of catatonia, but there is the possibility of one of a movement disorder, and more recently he had suffered from a degree of tardive dyskinesia. Conversely, this patient did have frequent 
symptoms of psychoses over recent years requiring active treatment. Clozapine, which this patient is now receiving, has been shown to be of value after an episode of NMS

special articles

(Weller \& Kornhuber, 1992). However, atypical antipsychotics including clozapine, olanzapine and risperidone may also cause NMS and catatonia. Clozapine is not available on the Japanese market owing to reports of malignant hyperthermia.

Despite the decline in the prevalence of classical catatonia, we should remain alert to it, and to NMS. While remaining aware of the benefits that traditional neuroleptics have brought, and their continuing value as part of a package of treatment in the emergency situation, we must continue to use them with caution. When catatonia does occur, a prompt response and liaison between psychiatrists and physicians is essential.

\section{References}

ADDONIZIO, G., SUSMAN,V. L. \& ROTH S. D. (1986) Symptoms of neuroleptic malignant syndrome in 82 consecutive inpatients. American Journal of Psychiatry, 143, 1587-1590.

BLUMER, D. (1997) Catatonia and the neuroleptics: psychobiologic significance of remote and recent findings. Comprehensive Psychiatry, 38(4), 193-201.

CASTILLO, E., RUBIN, R. T. \& HOLSBOERTRACHSLER, E. (1989) Clinical differentiation between letha catatonia and neuroleptic malignant syndrome. American Journal of Psychiatry, 146(3), 324-328.
DELAY, J. \& DENIKER, P. (1968) Druginduced extra-pyramidal syndromes. In Handbook of Clinical Neurology.Vol. 6. Diseases of the Basal Ganglia (eds P. S. Vinken \& G.W. Bruyn), pp. 248-266. New York: Elsevier North-Holland.

JOHNSON, J. (1993) Catatonia: the tension insanity. British Journal of Psychiatry, 162, 733-738.

KAHLBAUM, K. L. (1973) Die Katonie, Oder Das Spannungs Irresein (trans.

Y. Levii \& T. Pridan). Baltimore: Johns Hopkins University Press.

KELLAM, A. M. P. (1987) The neuroleptic malignant syndrome, so-called. A survey of the world literature. British Journal of Psychiatry, 150, 752-759.

LEVINSON, D. F. \& SIMPSON, G. M. (1986) Neuroleptic-induced extrapyramidal symptoms with fever. Archives of General Psychiatry, 43, 839-848.
MAYER-GROSS,W., SLATER, E. \& ROTH, M. (1960) Clinical Psychiatry (2nd ed). London: Cassell.

MURRAY, R., HILL, P. \& MCGUFFIN, P. (eds) (1997) The Essentials of Postgraduate Psychiatry. Cambridge: Cambridge University Press.

NORTHOFF, G.,WENKE, J. \& PFLUG, B. (1996) Increase of serum creatinine phosphokinase in catatonia. Psychological Medicine, 26(3), 547-553.

OSMAN, A. A. \& KHURASANI, M. H. (1994) Lethal catatonia and neuroleptic malignant syndrome. A dopamine receptor shut-down hypothesis. British Journal of Psychiatry, 165, 548-550.

WELLER, M. \& KORNHUBER, J. (1992) Clozapine rechallenge after an episode of neuroleptic malignant syndrome. British Journal of Psychiatry, 161 $855-856$

\footnotetext{
*Stephen James Carey MRCGP MRCPsych, Consultant Psychiatrist, Stratheden Hospital, Cupar, Fife KY15 5RR, David John Hall MB ChB MRCPsych, Consultant Psychiatrist, Crichton Royal Hospital, Dumfries DG1 4TG, Gwyneth Anwyl Jones BMedSci MRCP(UK), Consultant Physician, Dumfries \& Galloway Royal Infirmary, Dumfries DG1 4AP
}

\section{Psychiatric training in India}

With the population of India recently increasing to over 1 billion, the need for personnel to cater to the health services is ever increasing. This article will touch upon various aspects of psychiatric training in India and briefly cover some aspects of psychiatric practice and services in the country.

\section{Health care services and medical training}

India comprises 28 states, with each state having its own health care delivery service. The central government's Ministry of Health and Family Welfare is responsible for policy development and there are a large number of centrally funded health care delivery institutions. India has a large government funded health care system, although standards of care and funding vary. The private sector has been increasing year by year and there are many independently practising general practitioners and specialists and a network of private hospitals. The government funded service functions on a three tier level, with primary health centres covering a defined area. The secondary level comprises various district hospitals. On the tertiary level are various medical colleges and centrally funded hospitals with subspecialities.

India has one of the largest number of doctors in training in the world, with 17000 students entering medical school every year. Medical graduates train in state or centrally funded medical colleges. There are about 162 medical colleges (Ministry of Health and Family Welfare website: http://mohfw.nic.in). Medical training in government funded colleges is relatively cheap. Competition to enter medical training is high, with a few hundred thousand students competing in a common entrance examination. Additionally, there are 49 private medical colleges and the number is increasing. These colleges have their own entrance system and fees can be high.

\section{Training to be a psychiatrist}

Doctors train for 4-and-a-half years, after which they do a year of internship (equivalent to house officer) and are ready for postgraduate training. Emphasis on training in psychiatry during undergraduate training is dismally low; the Medical Council of India guidelines show that students are required to participate only in a 2-week programme of clinical postings, excluding a number of theory lectures. Also, the staff teaching the undergraduates are relatively junior and not fully trained in teaching methodology, curriculum planning and use of teaching aids (Alexander \& Kumaraswamy, 1995). Those interested in gaining experience can work as junior residents 